\title{
Potential Tumor or Organ Imaging Agents-31. Radioiodinated Sterol Benzoates and Carbamates
}

\author{
M. VAN DORT, L. SANTAY, S. W. SCHWENDNER and R. E. COUNSELL* \\ Department of Pharmacology, The University of Michigan Medical School, \\ Ann Arbor, MI 48109-0626, U.S.A.
}

(Received 9 December 1988)

\begin{abstract}
A series of radioiodinated benzoate and carbamate esters of cholesterol and pregnenolone wherein the acyl moiety served as the carrier for radioiodine was synthesized and evaluated as potential imaging agents for the adrenal cortex. 2,6-Dimethyl-3-iodobenzoyl and $\mathrm{N}$-(4-iodophenyl) carbamoyl groups were chosen as the acyl functionality in an attempt to provide esters resistant to in vivo hydrolysis. Tissue disposition studies in rats revealed that their biodistribution was determined by the attached sterol carrier-the cholesterol esters demonstrated significant uptake at $24 \mathrm{~h}$ in the adrenal whereas the corresponding pregnenolone derivatives showed only slight affinity for steroid-secreting tissues at this time.
\end{abstract}

Cholesterol is the principal metabolic precursor in the synthesis of adrenocortical hormones. This observation had led to the development of several radiolabeled cholesterol analogs as imaging agents for the adrenal cortex (Counsell et al., 1970; Hawkins et al., 1980; Maeda et al., 1975). Although $6 \beta-\left[{ }^{[3 !}\right.$ I]iodo methyl-19-norcholest-5(10)-en-3 $\beta$-ol is the current agent of choice for adrenal imaging, it suffers from several limitations. The initial high uptake of this agent in tissues such as liver, colon and gall bladder requires that adrenal imaging be performed $4-5$ days following i.v. adminstration in order to obtain a favorable adrenal to hackground ratio (Thrall et al., 1978). Moreover, the long biological half-life of this agent in the adrenals coupled with the relatively long half-life of ${ }^{131} \mathrm{I}\left(t_{1 / 2}=8\right.$ days) leads to a significant radiation dose to this organ (Thrall et al., 1978). The development of an agent that would be rapidly and selectively taken up by the adrenals has been a major goal of our studies in that it would permit the use of the shorter-lived ${ }^{123} \mathrm{I}\left(t_{1 / 2}=13 \mathrm{~h}\right)$. Employment of ${ }^{123} \mathrm{I}$ would not only reduce the radiation dose to the patient, but also provide a radiopharmaceutical suitable for single photon emission computed tomography (SPECT).

In previous papers we described the avid uptake displayed by a series of radioiodinated benzoate esters of cholesterol and pregnenolone into steroid-

*Correspondence should be addressed to R.E. Counsell, Department of Pharmacology, M6322 Med. Sci. Bldg I, Ann Arbor, MI 48109-0626, U.S.A. secreting tissues (adrenal and ovary) and the liver (Counsell et al., 1981; Seevers et al., 1982a, Van Dort, 1984). The retention of such esters in these tissues appeared to be related to their in vivo stability to hydrolysis (Seevers et al., 1982a,b; Van Dort et al., 1984). In particular, those analogs in which bulky groups were present in close proximity to the carbonyl of the ester functionality (e.g. the $\alpha$-ethyl group in cholesteryl iopanoate and the ortho iodine in pregnenolone 2,3,5-triiodobenzoate) displayed appreciable retention in steroid-secreting tissues (Seevers et al., 1982a; Van Dort, 1984). In an effort to uncover other hydrolytically stable derivatives of pregnenolone and cholesterol the 2,6-dimethyl-3iodobenzoate and 4-iodophenyl carbamate ester of these sterols were synthesized. This paper reports on the synthesis and preliminary biological evaluation of these ${ }^{125} \mathrm{I}$-labeled steroid esters in rats.

\section{Experimental}

Melting points were obtained in open capillary tubes with a Thomas-Hoover apparatus and are uncorrected. NMR spectra were obtained on a Varian EM360 A spectrometer with $\mathrm{CDCl}_{3}$ as solvent. Chemical shifts $(\delta)$ are reported in parts per milllion (ppm) downfield from tetramethylsilane, which was used as the internal stardard. Infrared spectra were obtained in the form of thin $\mathrm{KBr}$ wafers and recorded on a Perkin-Elmer 281 spectrophotometer. Elemental analyses were performed by Midwest Microlab Ltd, Indianapolis, Ind. All analyses 
$(\mathrm{C}, \mathrm{H}, \mathrm{N}, \mathrm{I})$ are within $\pm 0.4 \%$ of the calculated values. Thin-layer chromatography (TLC) was done with Analtech preadsorbent glass-backed silica gel plates with fluorescent indicator. Chromatograms of radiolabeled compounds were scanned with a Vanguard 930 autoscanner. Column chromatography was done on silica gel from Grace Davison Chemical, Baltimore, Md. Cholesterol and pregnenolone were kindly supplied by G. D. Searle and Co., Skokie, I1I. Sodium ${ }^{125}$ I was obtained from New England Nuclear, Boston, Mass. Tween 20 was obtained from Sigma Chemical Co., St Louis, Mo. Rats were obtained from Harlan Sprague Dawley, Inc., Hasslett, Mich. Chromatography (TLC) of tissue extracts were performed on plastic-backed silica gel plates with fluorescent indicator from Eastman Kodak Co.

\section{2,6-Dimethyl-3-nitrobenzoic acid (1)}

2,6-Dimethylbenzoic acid $(3.0 \mathrm{~g}, 20 \mathrm{mmol})$ was nitrated according to a previously published procedure (Mandell et al., 1961) to afford $3.2 \mathrm{~g}(82 \%)$ of 1: m.p. $114-116^{\circ} \mathrm{C}$ (Benzene); lit. (Mandell et al., 1961) $111-115^{\circ} \mathrm{C}$ (ligroin); i.r. (KBr); $1700 \mathrm{~cm}^{-1}$ $(\mathrm{C}=0) ;{ }^{1} \mathrm{H}$ NMR $\left(\mathrm{CDCl}_{3}\right): \delta 10.35(\mathrm{~s}, \mathrm{l}, \mathrm{COOH}), 7.96$ (d, $1, \mathrm{H}-4, \mathrm{~J}=9 \mathrm{~Hz}), 7.27$ (d, 1, H-5, J = 9Hz), 2.58 $\left(\mathrm{s}, 3,2-\mathrm{CH}_{3}\right), 2.50\left(\mathrm{~s}, 3,6-\mathrm{CH}_{3}\right)$.

\section{2,6-Dimethyl-3-aminobenzoic acid (2)}

A solution of $1(2.65 \mathrm{~g}, 13.6 \mathrm{mmol})$ in absolute ethanol $(150 \mathrm{~mL})$ was treated with $\mathrm{PtO}_{2}(0.26 \mathrm{~g})$ and hydrogenated at $45 \mathrm{psi}$ until the stoichiometric amount of $\mathrm{H}_{2}$ was absorbed. The precipitated amine was isolated by filtration along with the catalyst and the residue reconstituted in boiling THF $(400 \mathrm{~mL})$. The catalyst was removed by filtration and the filtrate evaporated in vacuo. This provided a solid residue which was purified by washing with ice-cold THF $(10 \mathrm{~mL})$. Drying under high vacuum afforded $2.04 \mathrm{~g}(91 \%)$; m.p. $276-278^{\circ} \mathrm{C}$ (d); i.r. (KBr): $3100-$ $2800 \mathrm{~cm}^{-1}$ (amine salt); $1615 \mathrm{~cm}^{-1}(\mathrm{C}=0) ;{ }^{1} \mathrm{H}$ NMR $\left(\mathrm{CDCl}_{3}\right): \delta 7.93-6.80\left(\mathrm{br} \mathrm{s}, 3,-\mathrm{NH}_{3}\right.$, exch. with $\mathrm{D}_{2} \mathrm{O}$ ), $6.81(\mathrm{~d}, \mathrm{l}, \mathrm{H}-4, \mathrm{~J}=8 \mathrm{~Hz}), 6.58(\mathrm{~d}, 1, \mathrm{H}-5, \mathrm{~J}=\mathrm{Hz}$ ), $2.10\left(\mathrm{~s}, 3,2-\mathrm{CH}_{3}\right) 1.96\left(\mathrm{~s}, 3,6-\mathrm{CH}_{3}\right)$. Anal. calc. for $\mathrm{C}_{9} \mathrm{H}_{11} \mathrm{NO}_{2}: \mathrm{C}, 65.43 ; \mathrm{H}, 6.71 ; \mathrm{N}, 8.48$. Found: $\mathrm{C}$, $65.19 ; \mathrm{H}, 6.93 ; \mathrm{N}, 8.35$.

\section{2,6-Dimethyl-3-iodobenzoic acid (3)}

A slurry of $2(1.50 \mathrm{~g}, 9.1 \mathrm{mmol})$ in a mixture of concentrated $\mathrm{H}_{2} \mathrm{SO}_{4}(2.5 \mathrm{~mL})$ and $\mathrm{H}_{2} \mathrm{O}(5.0 \mathrm{~mL})$ at $5^{\circ} \mathrm{C}$ (ice bath) was treated to the dropwise addition of $\mathrm{NaNO}_{2}(0.63 \mathrm{~g}, 9.1 \mathrm{mmol})$ in $\mathrm{H}_{2} \mathrm{O}(2.5 \mathrm{~mL})$. Upon completion of the addition the clear yellow solution was maintained at $0^{\circ} \mathrm{C}$ for a further $2 \mathrm{~h}$. The cold diazonium salt solution was then treated in one portion with a prechilled solution $\left(0^{\circ} \mathrm{C}\right)$ of $\mathrm{KI}(1.50 \mathrm{~g}$, $9.1 \mathrm{mmol})$ and $\mathrm{I}_{2}(1.15 \mathrm{~g}, 4.6 \mathrm{mmol})$ in $\mathrm{H}_{2} \mathrm{O}(2.5 \mathrm{~mL})$. The reaction mixture was stirred for $16 \mathrm{~h}$ at room temperature and then warmed at $70^{\circ} \mathrm{C}$ for $0.5 \mathrm{~h}$ on the steam bath. The aqueous suspension was treated with solid $\mathrm{NaHSO}_{3}(1.0 \mathrm{~g})$, filtered, and dried under high vacuum to afford $2.60 \mathrm{~g}$ of crude material. Column chromatography on silica gel with hexanes:EtoAc:HOAc (100:100:0.5) as eluant gave $2.1 \mathrm{~g}(83 \%)$ of analytically pure material, m.p. 115 $117^{\circ} \mathrm{C}$ (d); i.r. $(\mathrm{KBr}): 1692 \mathrm{~cm}^{-1}(\mathrm{C}=0) ;{ }^{1} \mathrm{H}$ NMR $\left(\mathrm{CDCl}_{3}\right): \delta 10.62$ (br s, 1, COOH), 7.87 (d, 1, H-4, $\mathrm{J}=8 \mathrm{~Hz}), 6.83(\mathrm{~d}, \mathrm{l}, \mathrm{H}-5, \mathrm{~J}=8 \mathrm{~Hz}), 2.56(\mathrm{~s}, 3$, $\left.2-\mathrm{CH}_{3}\right), 2.40\left(\mathrm{~s}, 3,6-\mathrm{CH}_{3}\right)$. Anal. calc. for $\mathrm{C}_{9} \mathrm{H}_{9} \mathrm{IO}_{2}$ : c, 39.16; H, 3.28; I, 45.97. Found: C, 39.49; H, 3.38; I, 45.73.

\section{2,6-Dimethyl-3-iodobenzoyl chloride (4)}

A solution of $3(1.5 \mathrm{mmol})$ in thionyl chloride $(4.0 \mathrm{~mL})$ was refluxed for $1.5 \mathrm{~h}$ under a nitrogen atmosphere. The solvent was evaporated in vacuo and the residual thionyl chloride was removed by azeotropic distillation with dry benzene $(4 \times 5 \mathrm{~mL})$. Final traces of thionyl chloride were removed by drying the crude product overnight under high vacuum. This crude product was used for the synthesis of the sterol esters without further purification.

General procedure for synthesis of the sterol esters 5 and 6

A solution of the acid chloride $4(1.5 \mathrm{mmol})$ in dry benzene $(8 \mathrm{~mL})$ was treated with the appropriate sterol $(1.5 \mathrm{mmol})$ and triethylamine $(0.167 \mathrm{~g}$, $1.65 \mathrm{mmol}$ ) and refluxed under nitrogen for $16 \mathrm{~h}$. The product was taken up in benzene $(50 \mathrm{~mL})$, washed with $0.5 \mathrm{~N} \mathrm{HCl}(2 \times 5 \mathrm{~mL})$, saturated aqueous $\mathrm{NaHCO}_{3}(1 \times 50 \mathrm{~mL})$, saturated brine $(1 \times 50 \mathrm{~mL})$, and dried $\left(\mathrm{MgSO}_{4}\right)$. The solvent was evaporated to dryness under reduced pressure and the residue chromatographed on silica with EtOAc:hexanes (1:4) as eluant to afford the sterol ester. Analytically pure material was obtained by recrystallization from a suitable solvent.

\section{Cholesteryl-2,6-dimethyl-3-iodobenzoute (5)}

Yield of $64 \%$; m.p. $162-164^{\circ} \mathrm{C}$ (acetone); i.r. $(\mathrm{KBr}): 1730 \mathrm{~cm}^{-1}(\mathrm{C}=0) ;{ }^{1} \mathrm{H}$ NMR $\left(\mathrm{CDCl}_{3}\right)$ : $\delta 7.70$ (d, l, Ph- $\mathrm{H}_{4}, \mathrm{~J}=8.0 \mathrm{~Hz}$ ); 6.70 (d, $1, \mathrm{Ph}-\mathrm{H}_{5}$, $\mathrm{J}=8.0 \mathrm{~Hz}) ; 5.40$ (d, $1, \mathrm{H}-6) ; 2.37\left(\mathrm{~s}, 3,2-\mathrm{CH}_{3}\right) ; 2.25$ (s, 3, 6- $-\mathrm{CH}_{3}$ ). Anal. calc. for $\mathrm{C}_{36} \mathrm{H}_{53} \mathrm{IO}_{2}: \mathrm{C}, 67.07 ; \mathrm{H}$, 8.28; I, 19.68. Found: C, 66.88; H, 8.52; I, 19.70.

\section{Pregnenolone-2,6-dimethyl-3-iodobenzoate (6)}

Yield of $54 \%$; m.p. $154-156^{\circ} \mathrm{C}$ (acetone); i.r. (KBr): $1728 \mathrm{~cm}^{-1}$ (ester $\mathrm{C}=0$ ), $1679 \mathrm{~cm}^{-1}$ (aceto $\mathrm{C}=0$ ); ${ }^{1} \mathrm{H}$ NMR $\left(\mathrm{CDCl}_{3}\right): \delta 7.78\left(\mathrm{~d}, \mathrm{l}, \mathrm{Ph}-\mathrm{H}_{4}, \mathrm{~J}=7.8 \mathrm{~Hz}\right), 6.77$ (d, l, Ph- $\mathrm{H}_{5}, \mathrm{~J}=7.8 \mathrm{~Hz}$ ), 5.50 (d, l, H-6), 4.96 (br m, $1, \mathrm{H}-3), 2.40\left(\mathrm{~s}, 3,2-\mathrm{CH}_{3}\right), 2.28\left(\mathrm{~s}, 3,6-\mathrm{CH}_{3}\right), 2.15(\mathrm{~s}$, 3, 21- $\mathrm{CH}_{3}$ ). Anal. Calc. for $\mathrm{C}_{30} \mathrm{H}_{39} \mathrm{IO}_{3}: \mathrm{C}, 62.72 ; \mathrm{H}$, 6.84; I, 22.09. Found: C, 62.69; H, 6.73; I, 21.84 .

\section{General procedure for preparation of sterol carbamates}

A solution of the sterol $(1.0 \mathrm{mmol})$ and 4-iodophenylisocyanate $(1.0 \mathrm{mmol})$ in dry benzene $(15 \mathrm{~mL})$ was refluxed for $16 \mathrm{~h}$ under a nitrogen atmosphere. The residue obtained following removal of the solvent 
Table 1. Distribution of radioactivity at 0.5 and $24 \mathrm{~h}$ after i.v. administration of ${ }^{125} \mathrm{I}$ labeled sterol esters

\begin{tabular}{lcccc}
\hline Tissue & $\begin{array}{c}\text { Cholesteryl } \\
\text { benzoate (5) }\end{array}$ & $\begin{array}{c}\text { Pregnenolone } \\
\text { benzoate (6) }\end{array}$ & $\begin{array}{c}\text { Cholesteryl } \\
\text { carbamate (7) }\end{array}$ & $\begin{array}{c}\text { Pregnenolone } \\
\text { carbamate (8) }\end{array}$ \\
\hline $0.5 \mathrm{~h}$ & & & & \\
Adrenal cortex & $5.87 \pm 0.51^{*}$ & $4.02 \pm 0.54$ & $6.57 \pm 1.09$ & $2.33 \pm 2.32$ \\
Blood & $7.20 \pm 0.54$ & $1.47 \pm 0.10$ & $3.18 \pm 0.19$ & $0.88 \pm \mathbf{0 . 0 4}$ \\
Kidney & $0.73 \pm 0.14$ & $0.63 \pm 0.07$ & $0.36 \pm 0.07$ & $0.53 \pm 0.07$ \\
Liver & $3.09 \pm 0.48$ & $1.51 \pm 0.12$ & $6.41 \pm 0.56$ & $0.69 \pm 0.00$ \\
Ovary & $6.41 \pm 2.43$ & $1.20 \pm 0.24$ & $3.45 \pm 0.86$ & $0.59 \pm 0.10$ \\
Thyroid & $1.56 \pm 0.11$ & $83.41 \pm 27.89$ & $3.13 \pm 1.23$ & $157.99 \pm 38.65$ \\
24h & & & & \\
Adrenal cortex & $25.58 \pm 4.88$ & $1.46 \pm 0.32$ & $11.32 \pm 2.60$ & $0.19 \pm 0.04$ \\
Blood & $1.17 \pm 0.26$ & $0.07 \pm 0.00$ & $0.50 \pm 0.05$ & $0.10 \pm 0.04$ \\
Kidney & $0.43 \pm 0.08$ & $0.08 \pm 0.00$ & $0.38 \pm 0.04$ & $0.09 \pm 0.01$ \\
Liver & $8.24 \pm 1.07$ & $0.33 \pm 0.04$ & $8.56 \pm 1.19$ & $0.15 \pm 0.02$ \\
Ovary & $30.86 \pm 4.51$ & $1.57 \pm 0.16$ & $10.15 \pm 3.09$ & $0.19 \pm 0.04$ \\
Thyroid & $31.96 \pm 8.64$ & $800.94 \pm 321.23$ & $70.30 \pm 12.06$ & $1399.12 \pm 314.37$ \\
\hline
\end{tabular}

* Values expressed as \% administered dose per gram of tissues \pm SD $(n=3-4)$.

under reduced pressure was chromatographed on a silica gel column with EtOAc: hexanes $(1: 4)$. Recrystallization from acetone afforded analytically pure material.

\section{$N$-(4-Iodophenyl)cholesteryl-3-carbamate (7)}

Yield of $94 \%$; m.p. $176-177^{\circ} \mathrm{C}$; i.r. (KBr): $1728 \mathrm{~cm}^{-1}(\mathrm{C}=0) .{ }^{1} \mathrm{H}$ NMR $\left(\mathrm{CDCl}_{3}\right): \delta 7.68(\mathrm{~d}, 2$, $\mathrm{Ph}-\mathrm{H}) ; 7.22$ (d, 2, Ph-H); 6.58 (s, 1, NH); 5.43 (br m, 1, H-6); 4.62 (br m, 1, H-3). Anal. calc. for $\mathrm{C}_{34} \mathrm{H}_{50} \mathrm{INO}_{2}: \mathrm{C}, 64.64 ; \mathrm{H}, 7.98 ; \mathrm{N}, 2.22$. Found: $\mathrm{C}$, $64.84 ; \mathrm{H}, 7.89 ; \mathrm{N}, 2.12$.

\section{$N$-(4-lodophenyl)pregnenolone-3-carbamate (8)}

Yield of $93 \%$; m.p. $225-227^{\circ} \mathrm{C}$ (d) i.r. (KBr): $1732 \mathrm{~cm}^{-1}$ (carbamate $\mathrm{C}=0$ ) $1694 \mathrm{~cm}^{-1}$ (aceto $\mathrm{C}=0) ;{ }^{1} \mathrm{H}$ NMR $\left(\mathrm{CDCl}_{3}\right): \delta 7.66(\mathrm{~d}, 2, \mathrm{Ph}-\mathrm{H}) ; 7.20$ (d, 2, Ph-H); 6.64 (s, l, NH); 5.42 (br m, l, H-6); 4.62 (brm, l, H-3); 2.15 (s, 3, 21- $\mathrm{CH}_{3}$ ); 1.05 (s, 3, 19- $\mathrm{CH}_{3}$ ); $0.63\left(\mathrm{~s}, 3,18-\mathrm{CH}_{3}\right)$. Anal. calc. for $\mathrm{C}_{28} \mathrm{H}_{36} \mathrm{INO}_{3}$ : C, $59.89 ; \mathrm{H}, 6.46 ; \mathrm{N}, 2.49$. Found: C, 59.80; H, 6.61; N, 2.31 .

\section{Radioiodination with $\mathrm{Na}^{125 \mathrm{I}}$}

Radioiodination was accomplished by isotope exchange with $\mathrm{Na}^{125}$ in pivalic acid as previously described (Weichert et al., 1986). Purification of the radioiodinated compounds was achieved by column chromatography on silica gel using hexanes:EtOAc $(5: 2)$ for elution of the benzoate esters and hexanes: EtOAc $(3: 1)$ for elution of the carbamate esters. Radiochemical yiels were $78,55,58$ and $50 \%$ for ${ }^{125} \mathrm{I}$ labeled 5, 6, 7 and 8, respectively. The radiochemical purity of the radioiodinated esters was $>95 \%$ as determined by radio-TLC analysis. Specific activities of the labeled esters 5, 6, 7 and 8 were $0.50,0.32,0.37$ and $0.15 \mathrm{Ci} / \mathrm{mmol}$, respectively.

\section{Biodistribution studies}

The radiolabeled compounds were dissolved in benzene and Tween 20 and added. The benzene was evaporated under a stream of nitrogen and physiological saline was added. Any remaining benzene was removed by a stream of nitrogen until a clear solution
( $2-3 \%$ in Tween 20$)$ resulted. The radiolabeled compound, thus solubilized, was administered intravenously to aduit female Sprague-Dawley rats weighing 190-240 g. Three to four rats were used for each compound at each time period, and the dose ranged between 5 and $15 \mu \mathrm{Ci}$ per animal. The rats were killed by exsanguination under ether anesthesia at 0.5 and $24 \mathrm{~h}$ and the major organs were removed and blotted free of excess blood. Large organs were minced with scissors. Weighed samples of tissue were placed in cellulose acetate capsules and counted $(81-85 \%$ efficiency) in a well scintillation counter (Searle 1185). The results are summarized in Table 1.

\section{Analysis of extracted radioactivity from plasma and} tissues

Radioactivity was extracted from plasma, adrenal cortex and liver using the procedure described previously (Van Dort et al., 1987). A system of benzenc: ethyl acetate $(9: 1)$ was employed for TLC analysis of the lipid extracts. The plates were then developed with the appropriate solvent system for $14.5 \mathrm{~cm}$ and air-dried. The plates were cut into $1 \mathrm{~cm}$ strips starting $0.5 \mathrm{~cm}$ below the origin and continuing to the solvent front. Each strip was placed in a counting tube and assayed for radioactivity. Each unlabeled ester was cochromatographed with the radioactive samples and visualized with iodine vapor to serve as a reference standard.

\section{Results and Discussion}

The synthesis of the 2,6-dimethyl-3-iodobenzoate esters of cholestrol and pregnenolone (5 and 6) is outlined in Scheme 1. Nitration of commercially available 2,6-dimethylbenzoic acid afforded the 3-nitro derivative (1) which was reduced by catalytic hydrogenation over $\mathrm{PtO}_{2}$ to the corresponding amino analog (2). Diazotization of 2 and treatment of the diazonium intermediate with $\mathrm{KI} / \mathrm{I}_{2}$ afforded 2,6dimethyl-3-iobobenzoic acid (3). Our initial attempts at preparing the sterol esters of 3 by a direct dicyclohexylcarbodiimide (DCC) catalysed esterification were unsuccessful probably due to increased steric 


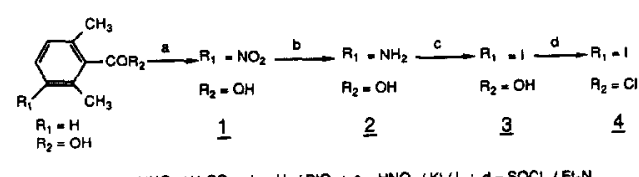

$\mathrm{a}=$ conc. $\mathrm{HNO}_{3} / \mathrm{H}_{2} \mathrm{SO}_{4}: \mathrm{b}=\mathrm{H}_{2} / \mathrm{PHO}_{2} ; C=\mathrm{HNO}_{2} / \mathrm{K} / / \mathrm{l}_{2}: d=S \mathrm{SOl}_{2} / \mathrm{E} \mathrm{H}_{3} \mathrm{~N}$

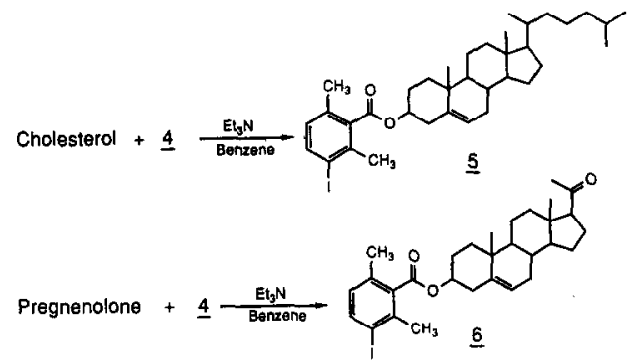

Scheme 1

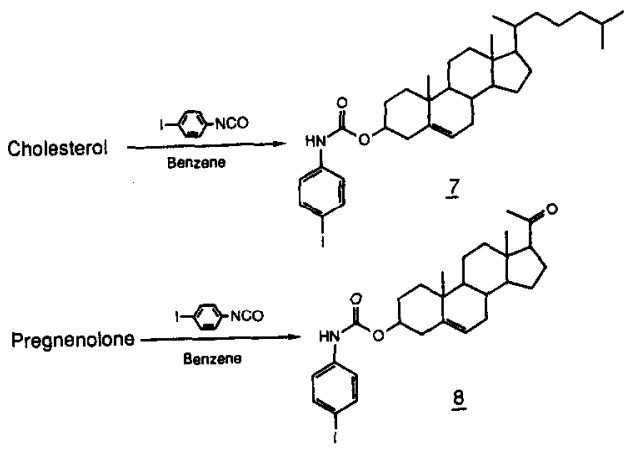

Scheme 2 hindrance afforded by the 2,6-dimethyl groups. However, these esters were prepared sucessfully by treatment of the appropriate sterol with the acid chloride $\mathbf{4}$, in the presence of triethylamine.

Synthesis of the iodophenylcarbamate esters of cholesterol and pregnenolone was achieved directly as shown in Scheme 2 by refluxing equimolar amounts of the appropriate sterol and 4-iodophenyl isocyanate. Radioiodination of these sterol esters was achieved by isotopic exchange in pivalic acid as previously described (Weichert et al., 1986). The radiolabeled compounds were solubilized in normal saline with the aid of Tween-20 prior to i.v. administration via the tail vein to female Sprague-Dawley rats. Groups of animals were sacrificed at 0.5 and $24 \mathrm{~h}$ and tissues were analyzed in a $\gamma$-counter for uptake of radioactivity. The results of these studies are summarized in Table 1. Although a total of twelve tissues were analyzed, only those tissues displaying high concentrations of radioactivity are tabulated. Analysis of the biodistribution profiles of these compounds revealed that their tissue disposition was determined by the attached sterol carrier. Similar findings have been reported by us previously (Seevers et al., 1982a: Van Dort et al., 1987). For example, both the carbamate and benzoate esters of cholesterol showed an ability to localize in the liver and steroidsecreting tissues. This accumulation was significant at $24 \mathrm{~h}$ with respect to the cholesteryl ester 5 which showed an uptake of over 25 and $30 \%$ of the injected dose per gram of tissue in the adrenals and ovaries, respectively. In the case of the carbamate ester 7 , the adrenal uptake at $0.5 \mathrm{~h}$ was similar to 5 , but the level at $24 \mathrm{~h}$ was only half that of 5 . Ester 5 was also superior to 7 towards accumulation in the ovary. Based upon lipid extraction of these tissues and TLC analysis of the extracts, the lower affinity of the carbamate for steroid-secreting tissue does not seem

Table 2. Analysis of lipid-soluble radioactivity extracted from tissues

\begin{tabular}{|c|c|c|c|c|}
\hline \multirow[b]{2}{*}{ Tissue } & \multicolumn{2}{|c|}{$\begin{array}{l}\% \mathrm{CHCl}_{3} / \mathrm{CH}_{3} \mathrm{OH} \\
\text { extractable compound }\end{array}$} & \multicolumn{2}{|c|}{$\begin{array}{l}\% \text { Parent compound } \\
\text { as determined by TLC* }\end{array}$} \\
\hline & $0.5 \mathrm{~h}$ & $24 \mathrm{~h}$ & $0.5 \mathrm{~h}$ & $24 \mathrm{~h}$ \\
\hline \multicolumn{5}{|c|}{ Cholesteryl benzoate (5) } \\
\hline Adrenal cortex & $\begin{array}{c}93.2 \pm 2.8 \\
(85.1 \pm 5.4) \dagger\end{array}$ & $\begin{array}{c}87.4 \pm 1.8 \\
(93.6 \pm 1.2)\end{array}$ & $\begin{array}{c}81.4 \pm 9.0 \\
(62.8 \pm 19.2)\end{array}$ & $\begin{array}{l}90.3 \pm 6.4 \\
63.6 \pm 5.8\end{array}$ \\
\hline Liver & $\begin{array}{l}92.4 \pm 2.8 \\
(64.3 \pm 4.0)\end{array}$ & $\begin{array}{c}90.0+3.6 \\
(91.2 \pm 2.2)\end{array}$ & $\begin{array}{l}85.6 \pm 1.2 \\
(76.2 \pm 1.2)\end{array}$ & $\begin{array}{c}81.2+24.4 \\
(47.0 \pm 14.4)\end{array}$ \\
\hline Plasma & $\begin{array}{c}87.8 \pm 3.6 \\
(48.5 \pm 7.2)\end{array}$ & $\begin{array}{l}92.3 \pm 4.8 \\
(73.7 \pm 10.8)\end{array}$ & $\begin{array}{c}91.9 \pm 1.2 \\
(66.4 \pm 5.2)\end{array}$ & $\begin{array}{c}91.4 \pm 2.3 \\
(12.0 \pm 7.6)\end{array}$ \\
\hline \multicolumn{5}{|c|}{ Cholesteryl carbamate (7) } \\
\hline Adrenal cortex & $\begin{array}{c}92.4 \pm 2.4 \\
(56.8 \pm 5.6) \ddagger\end{array}$ & $\begin{array}{c}88.7 \pm 1.4 \\
(78.1 \pm 3.4)\end{array}$ & $\begin{array}{c}64.7 \pm 9.2 \\
(83.2 \pm 6.0)\end{array}$ & $\begin{array}{c}85.6 \pm 4.8 \\
(48.8 \pm 40.4)\end{array}$ \\
\hline Liver & $\begin{array}{c}92.7 \pm 1.6 \\
(40.5 \pm 4.0)\end{array}$ & $\begin{array}{c}85.0 \pm 2.4 \\
(52.1 \pm 5.8)\end{array}$ & $\begin{array}{c}74.8 \pm 21.6 \\
(74.2 \pm 14.6)\end{array}$ & $\begin{array}{c}96.6 \pm 6.0 \\
(41.1 \pm 26.4)\end{array}$ \\
\hline Plasma & $\begin{array}{l}82.1 \pm 5.0 \\
(7.8 \pm 2.2)\end{array}$ & $\begin{array}{c}87.6 \pm 3.2 \\
(14.8 \pm 8.4)\end{array}$ & $\begin{aligned} 90.3 & \pm 3.0 \\
(63.5 & \pm 30.4)\end{aligned}$ & $\begin{array}{c}68.0 \pm 9.4 \\
(35.6 \pm 27.4)\end{array}$ \\
\hline
\end{tabular}

"Values represent the percent of total radioactivity \pm SD comigrating with parent compound on chromatogram.

$+\$$ Values in parentheses are the corresponding values obtained for pregnenolone-3-(2,6-demethyl-3iodobenzoate) (6) and pregnenolone-3-(4-iodophenylcarbamate) (8) respectively. 
to be explained by a greater susceptibility to in vivo hydrolysis (Table 2).

In marked contrast to the cholesterol derivatives, the benzoate and carbamate esters of pregnenolone (6 and 8) showed only slight affinity for steroidsecreting tissues. Furthermore these tissues displayed a rapid clearance of radioactivity by $24 \mathrm{~h}$ with a concomitant increase of radioactivity in the thyroid. This increase in thyroid radioactivity is believed to be related to deiodination following in vivo hydrolysis of these esters. Analysis of the adrenal, liver and plasma lipid extraction data (Table 2) provided further evidence as to the in vivo instability of the pregnenolone derivatives 6 and 8 . For example in the case of the pregnenolone carbamate (8) TLC analysis of the adrenal, liver and plasma extracts at $24 \mathrm{~h}$ revealed that only $48.8,41.1$ and $35.6 \%$ of the radioactivy associated with these tissues was still present as the original compound. In contrast the corresponding values for the cholesteryl analog 7 at this time interval were $85.6,96.6$ and $68.0 \%$, respectively.

In summary, despite the good accumulation of the radioiodinated cholesterol ester 5 in the adrenals, its concentration in this tissue at $24 \mathrm{~h}(26 \%$ of dose $/ \mathrm{g})$ does not differ significantly from 19-iodocholesterol (Van Dort et al., 1984). Although more easily synthesized than the latter, $\mathbf{5}$ does not appear to offer any appreciable tissuc localizing advantage over currently available radioiodinated cholesterols. A somewhat surprising observation was the lack of selectivity for adrenocortical tissue displayed by the pregnenolone esters examined in this study. This was in contrast to previous observations with a series of radioiodinated pregnenolone iodobenzoate esters which displayed high adrenal uptake (Van Dort et al., 1984). In conclusion, future attempts to achieve selective adrenal uptake through chemical manipulation should take into account the substrate specificity of the sterol ester hydrolases, of which little is known at the present time.
Acknowledgements - The authors wish to thank Tammy Granroth, Edie Quenby and Lisa Flaherty for their Technical assistance and for typing the manuscript. This research was supported by PHS Grant CA-08349 awarded by the National Cancer Institute.

\section{References}

Counsell, R. E.; Ranade, V. V.; Blair, R. J.; Beierwaltes, W. H.; Weinhold, P. A. Tumor localizing agents. IX. Radioiodinated cholesterol. Steroids 16:317; 1970.

Counsell, R. E.; Seevers, R. H.; Korn, N.; Schwendner S. W. Potential urgan or tumor-inaging agents. 21 . Acyl-labeled esters of cholesterol. J. Med. Chem. 24:5; 1981.

Hawkins, L. A.; Britton, K. E., Shapiro B. Selenium 75 selenomethyl cholesterol: a new agent for quantitative functional scintigraphy of the adrenals: physical aspects. Br. J. Radiol. 53:883; 1980.

Maeda, M.: Kojima, M; Ogawa, H.; Nitta, K.; Ito, T. Homoallylic rearrangement of 19 -iodocholest-5-en-3 $\beta$-ol: New adrenal scanning agent. Steroids 26:241; 1975.

Mandell, L.; Caine, D.; Kilpatrick, G. E. The synthesis of dienones related to santonin and $\psi$-santonin via aryl participation. J. Am. Chem. Soc. 83:4457; 1961 .

Seevers, R. H.; Groziak, M. P.: Weichert, J. P.; Schwendner, S. W.; Szabo, S. M.; Longino, M. A.; Counsell, R. E. Potential tumor or organ-imaging agents. 23. Sterol esters of iopanoic acid. J. Med. Chem. 25:1500; 1982a.

Seevers, R. H.; Schwendner, S. W.; Swayze, S. L., Counsell, R. E. Potential organ or tumor-imaging agents. 22. Acyl-labeled cholesterol esters. J. Med. Chem. 25:618; 1982b.

Thrall, J. H.; Freitas, J. E.; Beierwaltes, W. H. Adrenal scintigraphy. Semin. Nucl. Med. 8:23; 1978.

Van Dort, M.; Schwendner, S. W.; Counsell, R. E. Potential tumor or organ-imaging agents. 28. Radioiodinated esters of cholesterol and pregnenolone. Steroids 49:531; 1987.

Van Dart, M.; Schwendner, S. W.; Skinner, R. W. S.; Gross, M. D.; Counsell, R. E. Potential tumor or organ-imaging agents. 24. Radioiodinated pregnenolone esters. Steroids 44:85; 1984

Weichert, J. P.; Van Dort, M. E.; Groziak, M. P.; Counsell, R. E. Radioiodination via isotope exchange in pivalic acid. Appl. Radiat. Isot. 37:907; 1986 